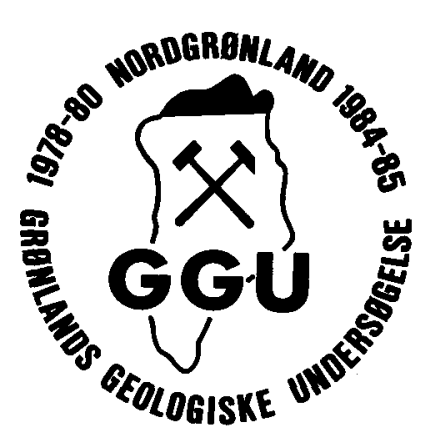

\title{
Thin-skinned structures at the basin-shelf transition in North Greenland
}

\author{
N. J. Soper and A. K. Higgins
}

\begin{abstract}
Description is given of the structural pattern in the southern part of the North Greenland fold belt between northern Nyeboe Land and Adolf Jensen Fjord. The structures prove to be of thin-skinned fold-and-thrust type with southerly vergence, quite distinct from that of the north-verging, multiply deformed orthotectonic zone to the north.
\end{abstract}

N. J. S., Department of Geology, University of Sheffield, Mappin Street, Sheffield S1 3JD, U.K.

A. K. H., Grønlands Geologiske Undersøgelse, $\emptyset$ ster Voldgade 10, DK-1350 Copenhagen K, Denmark.

The 1984 season provided an opportunity to examine the structure of the region which lies between the intensely deformed orthotectonic part of the North Greenland fold belt (Johannes V. Jensen Land, Nansen Land and adjacent islands) and the virtually undeformed platform to the south.

The orthotectonic zone of the North Greenland fold belt, which coincides with the position of the deep-water, Lower Palaeozoic, North Greenland basin (Surlyk \& Hurst, 1983, 1984), is characterised by several phases of northerly overturned E-W trending folds (Soper et al., 1980; Higgins et al., 1981, 1982); the northward overturning is, however, less pronounced in Nansen Land (fig. 1) than in areas farther east (Friderichsen \& Bengaard, 1985). Previously, during work in Johannes V. Jensen Land (Soper et al., 1981), it was not possible to link the structure southward to the platform margin because of the broad intervening region of imbricate thrusting in Amundsen Land (Pedersen, 1980) between the Harder Fjord fault zone and the platform margin feature of the Navarana Fjord lineament (fig. 2). This complex imbricate thrust zone is characterised by curved fold and thrust traces, with displacements to both west and south (Pedersen, 1980; Håkansson \& Pedersen, 1982). The study reported on here was concentrated in the vicinity of Adolf Jensen Fjord and J. P. Koch Fjord (fig. 1), but reconnaissance structural mapping was extended as far west as northern Nyeboe Land. Preliminary photogeological studies by one of us (AKH), together with observations made on a single helicopter traverse in 1980, suggested the presence of south-verging thrusts in J. P. Koch Fjord and at Kap Bopa, comparable in some respects but differing in trend from the west-verging thrusts mapped by Pedersen (1980) in Amundsen Land and along the inner part of Frederick E. Hyde Fjord. The structure of the region between northern Nyeboe Land and Adolf Jensen Fjord (fig. 1) proved in 1984 to be of typical thinskinned fold-and-thrust type, quite distinct from that of the north-verging, multiply deformed orthotectonic zone to the north. 


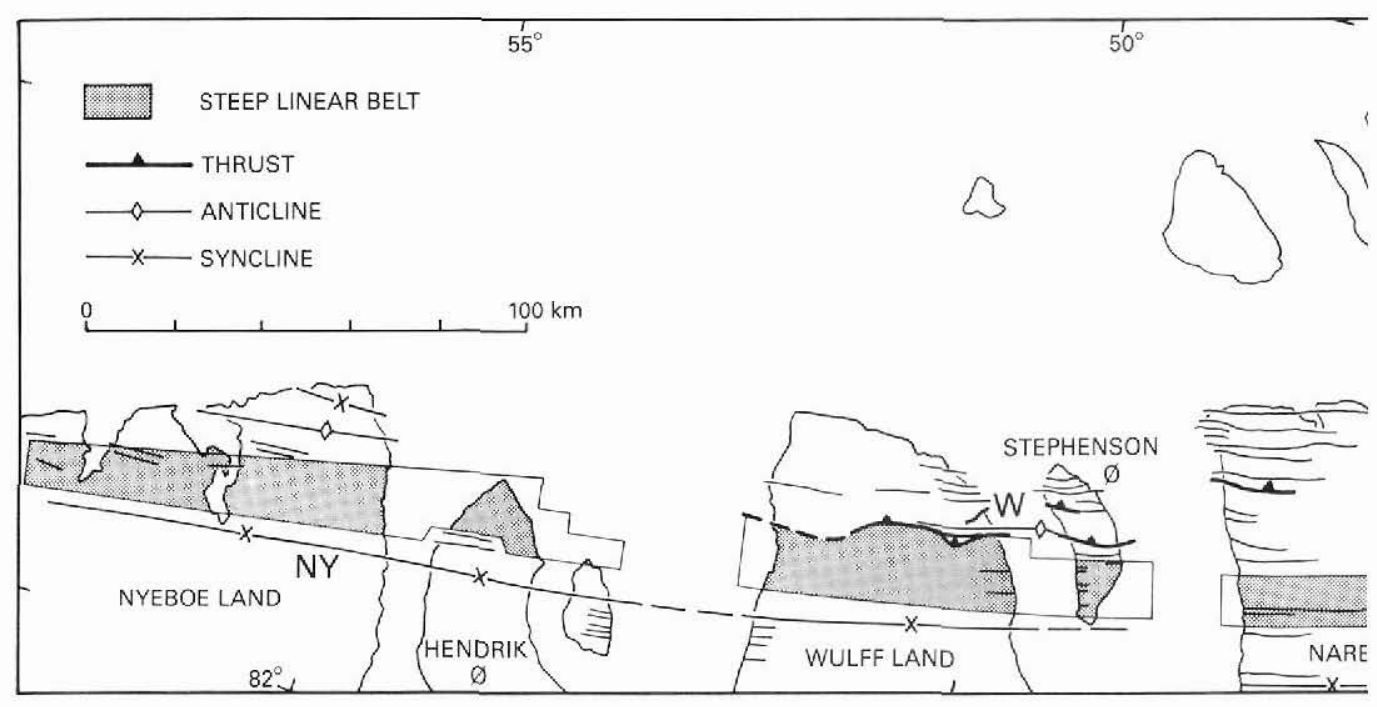

Fig. 1. Trace of principal structures in the thin-skinned fold-and-thrust zone. A: Amundsen Land imbricate zone. D: Dilemma Sund. F: Freuchen Land thrust zone. KB: Kap Bopa thrust zone. N: Navarana anticline. NY: Nyeboe Land syncline. W: Wulff Land anticline. Trace of Nyeboe Land syncline after Larsen \& Escher (1985), and Navarana Fjord lineament after Surlyk \& Hurst (1984) and photogeological studies. The cross-section of fig. 3 follows the east side of Adolf Jensen Fjord.

\section{Stratigraphic control of the structure}

Figure 2 illustrates how these two tectonic zones are related to the geometry of the Lower Palaeozoic deep-water clastic basin in North Greenland. The northern orthotectonic zone is developed on the site of the basin proper, with its thick fill of dominantly Lower Cambrian turbidites; Ordovician and Silurian clastics were presumably also present everywhere but have been largely removed by erosion. The southern zone with which this report is concerned coincides with a region which appears to have been transitional between the shelf and basin for much of the Cambrian and Ordovician. It is bounded to the south by the Navarana Fjord lineament, which represents the position to which the platform margin had retreated by early Silurian time (Surlyk \& Hurst, 1983, 1984). The sequence here is thinner than that of the platform to the south or the basin to the north and consists of a less than $1 \mathrm{~km}$ thickness of Cambrian - Lower Silurian sediments (equivalents of the Buen Formation and Vølvedal and Amundsen Land Groups - see Higgins \& Soper, 1985) exposed below the Silurian turbidites of the Peary Land Group. It takes the form of a multilayer, with strong competence contrasts between the weak mudrock horizons (Frigg Fjord mudstones and equivalent Buen Formation shales; sub-Portfjeld Formation shales) and the more rigid Portfjeld Formation carbonates (see also Higgins \& Soper, 1985). Some of the units of intermediate competence are strongly laminated, for example the cherts and dolomite mudstones of the Cambrian - Lower Silurian starved basin sequence. Depth to décollement calculations indicate major detachments along the two weak horizons mentioned above, with local thrust 

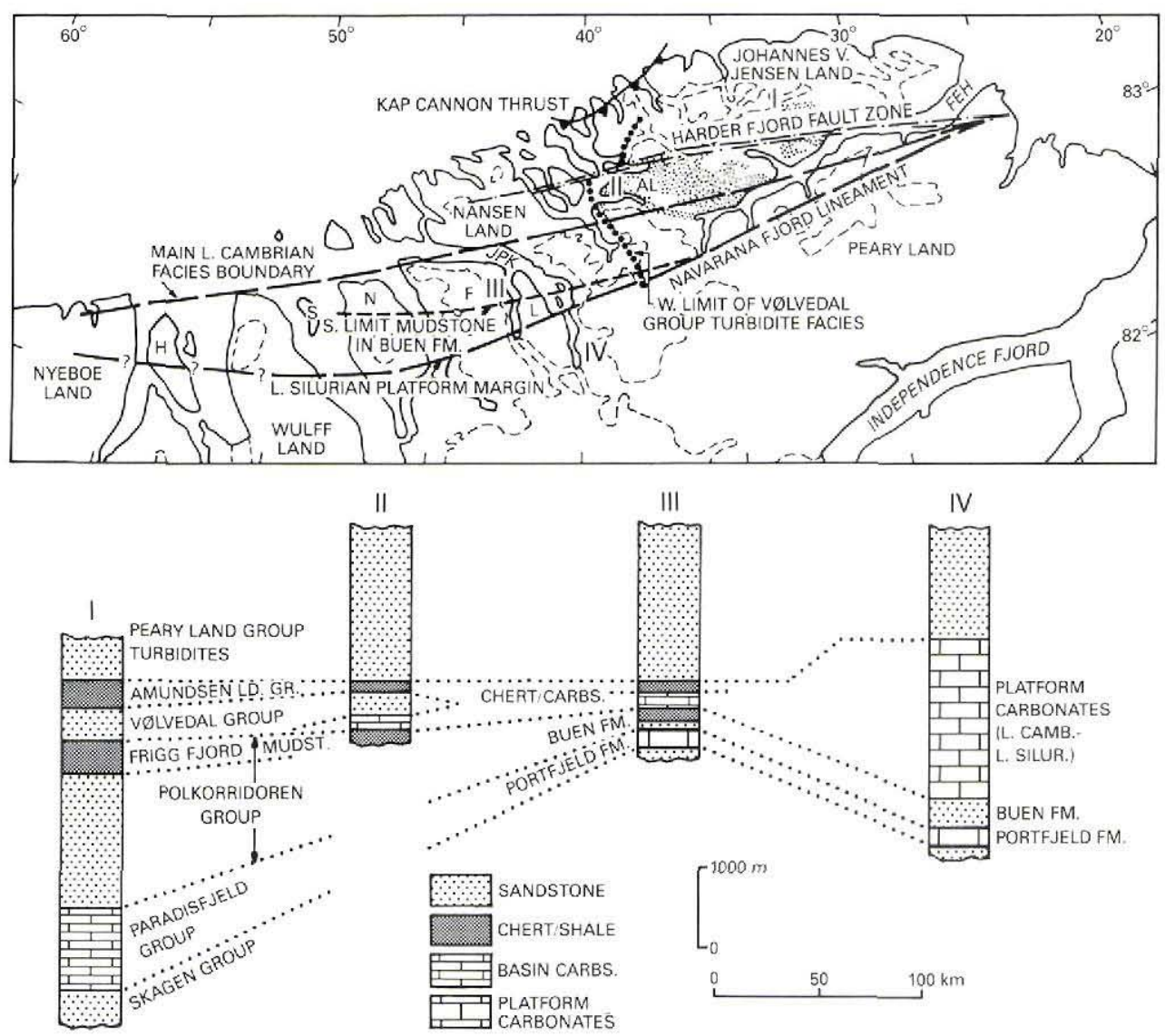

Fig. 2. Stratigraphic control of tectonic zones. AL: Amundsen Land. F: Freuchen Land. H: Hendrik $\varnothing$. L: Lauge Koch Land. N: Nares Land. S: Stephenson Ø. I, II, III and IV in map refer to approximate locations of columnar sections, which are constructed from published and unpublished Survey sources. Navarana Fjord lineament partly after Surlyk \& Hurst (1984) and photogeological studies. West limit of Vølvedal Group turbidites hypothetical north of Harder Fjord fault zone.

fig. 2 suggests that the terminal anticlines are located at the southern limit of incompetent mudstone units within the Buen Formation. The ramps below the folds cut steeply up through Cambrian - Lower Silurian rocks in the vicinity of the basin-shelf facies change.

Further north, a shallower detachment is inferred within the Peary Land Group (Merqujôq Formation), but below exposure level, ramping up from the main Frigg Fjord mudstone detachment in association with two medium-scale anticlines. Immediately to the north is a thrust with $3.5 \mathrm{~km}$ displacement which brings the Cambrian - Lower Silurian shales and cherts onto the Silurian turbidites of the Merqujôq Formation, and is cut off to the south by a normal fault. North again, examples of small thrusts losing displacement upwards into south-verging folds are well exposed. Total displacement between here and the platform margin is $7.5 \mathrm{~km}$. 
BALANCED SECTION ALONG ADOLF JENSEN FJORD

NORTH

\section{KAP BOPA}
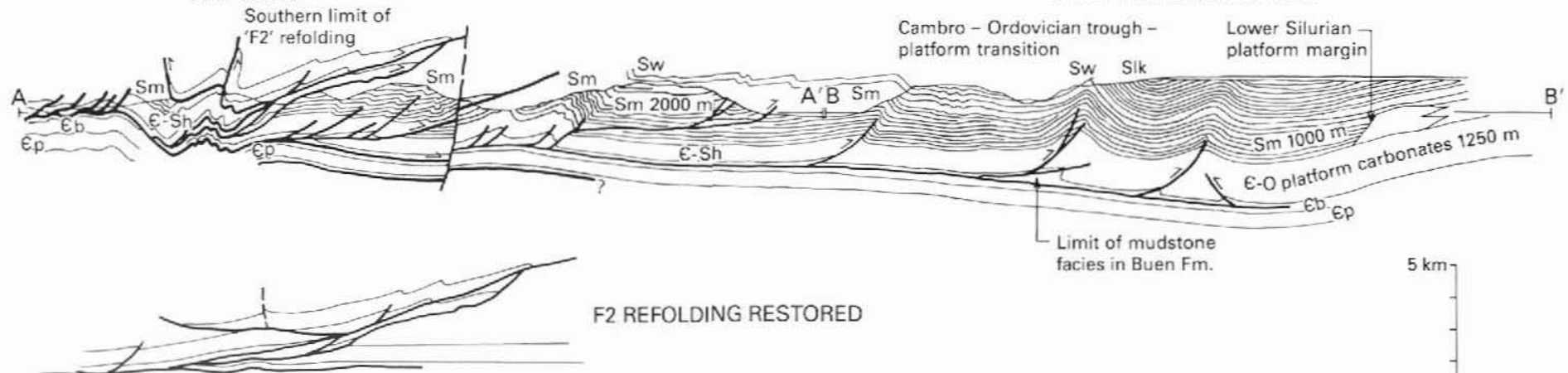

F2 REFOLDING RESTORED

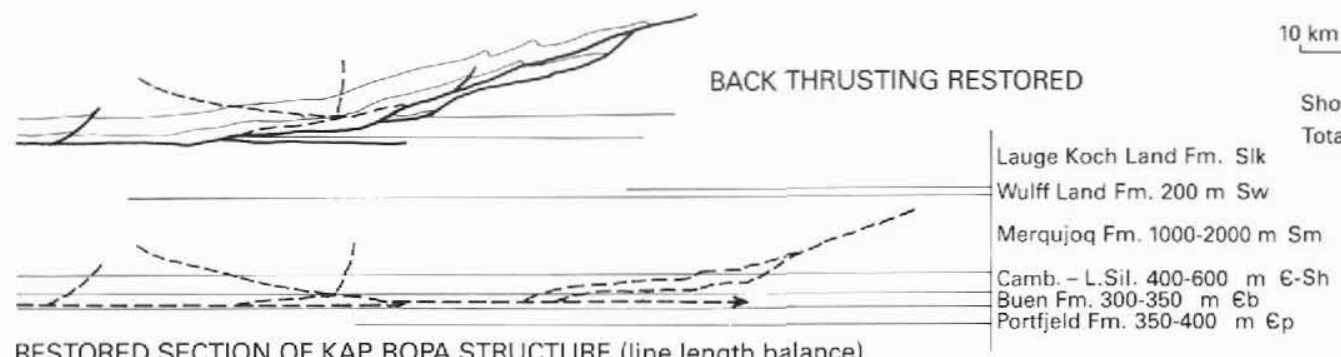

RESTORED SECTION OF KAP BOPA STRUCTURE (line length balance)

Fig. 3. Interpretative cross-section along the east side of Adolf Jensen Fjord, and stages in a restoration sequence of the structure at Kap Bopa. 
The structure at Kap Bopa is complex and proved difficult to disentangle in the field. It involves two southward thrusts with 4-5 km displacement and two refolded back-thrusts. A coherent interpretation has been achieved and fig. 3 illustrates several stages in a restoration sequence. The interpretation envisages southward thrusting towards the platform which locked where the detachment horizons run deeper beneath the southward-thickening Cambro-Ordovician sequence, followed by a further southwardly propagating wave of compression which resulted in back-thrusting and refolding at Kap Bopa. The latter deformation is thought to relate to the second phase structures of the northern orthotectonic zone, and thus Kap Bopa marks the southern limit of F2 refolding. Shortening across the Kap Bopa structure is $13 \mathrm{~km}$, of which $9 \mathrm{~km}$ is attributable to D1 and $4 \mathrm{~km}$ to D2.

North of Kap Bopa, the main thrust, with a D1 displacement of $16.5 \mathrm{~km}$, must root beneath the tract of Frigg Fjord mudstone which occupies Dilemma Sund, the E-W through valley in southern Nansen Land and the outer part of J. P. Koch Fjord. This tract is $8 \mathrm{~km}$ wide at its narrowest and it is probable that the mudstones are repeated by D1 imbricate thrusts. If $2.2 \mathrm{~km}$ is adopted as a minimum value for this imbrication, and a further $1 \mathrm{~km}$ for D2 cleavage formation, we arrive at an estimate of nearly $24 \mathrm{~km} \mathrm{~N}-\mathrm{S}$ shortening across the whole thin-skinned tectonic zone.

\section{Discussion}

The main detachment roots in a zone across which the northward vergence of the orthotectonic part of the fold belt changes to the southward vergence of the fold-and-thrust zone. The northward overturning in Johannes V. Jensen Land is due largely to the superimposition of D2 strain on D1 folds which were originally upright, and in the extreme north to the superimposition of D3 on both. We have interpreted the back-thrusting and refolding episode at Kap Bopa as the most southerly expression of D2 strain. Therefore the 'divergence zone' (fig. 1), which is an important tectonic feature of the North Greenland fold belt, is interpreted as both the southern limit of D2 strain and the root-zone of the thin-skinned thrusts.

Similar fold-and-thrust structures continue westwards to Wulff Land (fig. 1). The southernmost major syncline perhaps provides the best indication of the Cambro-Ordovician platform margin in areas where the older strata are obscured by Silurian turbidites (Larsen \& Escher, 1985). The whole zone narrows westwards and folds become more important than thrusts in that direction. As is common with flexural-slip folds, the traces lie en echelon and thrusts transfer displacement from one fold to another. In northern Nyeboe Land, the structure is dominated by a single south-facing monocline with a vertical limb some $5 \mathrm{~km}$ in width (Larsen \& Escher, 1985). The fold exposes Lower Cambrian strata to the north, Silurian to the south and thus has the same effect as the divergence zone, stepping the stratigraphy down to the south. As indicated in fig. 2, the early Cambrian and early Silurian positions of the platform margin may converge in this area, and the effect has apparently been to concentrate the deformation into a single large structure. In the east around Frederick E. Hyde Fjord where the various positions of the platform margin also seem to converge, the structural pattern is very complex and characterised by a broad zone of west verging imbricate thrusts (Pedersen, 1980).

The steeply dipping linear belt in northern Nyeboe Land and Wulff Land was first described by Dawes, who associated it with an apparent major dislocation, the Nyeboe Land 
fault zone (Dawes, 1982). We have been able to show that there is a conformable contact between Cambrian - Lower Silurian starved basin strata and the Silurian Peary Land Group in northern Nyeboe Land, only locally disturbed by minor thrusts, and there is no major fault zone. Farther east, the major north-dipping thrusts in northern Wulff Land and Stephenson $\emptyset$ were considered by Dawes (1982) as part of the fault zone but are now viewed as parts of the regional fold-and-thrust belt. Larsen \& Escher (1985) have mapped the linear belt as the vertical north limb of the Nyeboe Land syncline over an east-west distance of $170 \mathrm{~km}$. Photogeological studies (AKH) and field observations show that the steep belt can be traced as a coherent structural element as far east as Navarana Fjord (fig. 1). It changes character eastwards, narrowing and in some sections containing numerous tight folds which step the stratigraphy down to the south.

The thin-skinned thrust and fault zone between Nyeboe Land and Kap Bopa (fig. 1) clearly must continue eastwards into the complex imbricate thrust zone of the Amundsen Land region described by Pedersen (1980) and Håkansson \& Pedersen (1982). However, while the thrusts west of Kap Bopa all have E-W trends and a southward sense of displacement and are clearly part of the Ellesmerian deformation pattern, most of the Amundsen Land imbricate thrusts have curved trends ranging from E-W through NW-SE to N-S. Håkansson \& Pedersen (1982) consider the main displacement direction of the Amundsen Land thrusts to be westwards and relate it to a pre-Ellesmerian deformation phase (their 'Vølvedal orogeny'). The thrusts are considered to root in a major décollement zone in the Frigg Fjord mudstones with an accumulated westward transport of $100 \mathrm{~km}$, and to have arisen by gravity sliding from the rising East Greenland Caledonides (Håkansson \& Pedersen, 1982); the curved trends are attributed to refraction or deflection along the carbonate platform margin (Navarana Fjord lineament). Surlyk \& Hurst (1984) reject this hypothesis for various reasons, and propose that the thrusting was caused by transpression in connection with sinistral, up-to-north oblique-slip movements on the Harder Fjord fault zone. This we consider unlikely, as the present Harder Fjord fault zone is essentially post-Ellesmerian, and the only demonstrable movements are dextral and up-to-north (authors' observations).

As the E-W trending thrusts between Nyeboe Land and Kap Bopa (known to be Ellesmerian) appear to link up with E-W trending thrusts in the Amundsen Land region, then both groups are likely to be Ellesmerian. Together they form a $400 \mathrm{~km}$ long belt of southward directed thrusts along the southern margin of the (Ellesmerian) North Greenland fold belt. The main group of thrusts in the Amundsen Land region, with their arcuate trends and westwards displacement sense, are anomalous with respect to the general E-W Ellesmerian trends, but as they can be traced into E-W trending thrusts are probably also Ellesmerian. The aberrant westward displacement sense remains to be convincingly explained, but perhaps arose as a consequence of successive N-S directed waves of Ellesmerian deformation impinging obliquely against the buried platform margin escarpment (Navarana Fjord lineament).

\section{References}

Dawes, P. R. 1982: The Nyeboe Land fault zone: a major dislocation on the Greenland coast along northern Nares Strait. In Dawes, P. R. \& Kerr, J. W. (edit.) Nares Strait and the drift of Greenland: a conflict in plate tectonics. Meddr Grønland, Geosci. 8, 177-192. 
Friderichsen, J. D. \& Bengaard, H. J. 1985: The North Greenland fold belt in eastern Nansen Land. Rapp. Grønlands geol. Unders. 126, 69-78.

Higgins, A. K. \& Soper, N. J. 1985: Cambrian - Lower Silurian slope and basin stratigraphy between northern Nyeboe Land and western Amundsen Land, North Greenland. Rapp. Grønlands geol. Unders. 126, 79-86.

Higgins, A. K., Friderichsen, J. D. \& Soper, N. J. 1981: The North Greenland fold belt between central Johannes V. Jensen Land and eastern Nansen Land. Rapp. Grønlands geol. Unders. 106, 35-45.

Higgins, A. K., Mayr, U. \& Soper, N. J. 1982: Fold belts and metamorphic zones of northern Ellesmere Island and North Greenland. In Dawes, P. R. \& Kerr, J. W. (edit.) Nares Strait and the drift of Greenland: a conflict in plate tectonics. Meddr Grønland, Geosci. 8, 159-166.

Håkansson, E. \& Pedersen, S. A. S. 1982: Late Paleozoic to Tertiary tectonic evolution of the continental margin in North Greenland. In Embry, A. F. \& Balkwill, H. R. (edit.) Arctic geology and geophysics. Mem. Can. Soc. Petrol. Geol. 8, 331-345.

Larsen, P.-H. \& Escher, J. C. 1985: The Silurian turbidite sequence of the Peary Land Group between Newman Bugt and Victoria Fjord, western North Greenland. Rapp. Grønlands geol. Unders. 126.

Pedersen, S. A. S. 1980: Regional geology and thrust fault tectonics in the southern part of the North Greenland fold belt, north Peary Land. Rapp. Grønlands geol. Unders. 99, $79-87$.

Soper, N. J., Higgins, A. K. \& Friderichsen, J. D. 1980: The North Greenland fold belt in eastern Johannes V. Jensen Land. Rapp. Grønlands geol. Unders. 99, 89-98.

Surlyk, F. \& Hurst, J. M. 1983: Evolution of the early Paleozoic deep-water basin of north Greenland Aulacogen or narrow ocean? Geology 11, 77-81.

Surlyk, F. \& Hurst, J. M. 1984: The evolution of the early Paleozoic deep-water basin of North Greenland. Bull. geol. Soc. Am. 95, 131-154. 